University of New Orleans

ScholarWorks@UNO

1982

\title{
The Sexualization of Racism in Richard Wright's 'The Man Who Killed a Shadow'
}

Earle V. Bryant

University of New Orleans, ebryant@uno.edu

Follow this and additional works at: https://scholarworks.uno.edu/engl_facpubs

Part of the Literature in English, North America Commons

\section{Recommended Citation}

Bryant, Earle V. "The Sexualization of Racism in Richard Wright's 'The Man Who Killed a Shadow'." Black American Literature Forum 16.3 (1982): 119-121.

This Article is brought to you for free and open access by the Department of English and Foreign Languages at ScholarWorks@UNO. It has been accepted for inclusion in English Faculty Publications by an authorized administrator of ScholarWorks@UNO. For more information, please contact scholarworks@uno.edu. 
${ }^{3}$ The Negro Question in the United States (New York: International Publishers, 1936).

${ }^{4}($ London: n. p., n. d.), p. 8.

${ }^{5}$ Richard Wright, American Hunger (New York: Harper, 1977), p. 82

${ }^{6} \mathrm{~A}$ valuable discussion of the broad influence of the Chicago School on Wright's generation appears in Robert Bone's "Richard Wright and the Chicago Renaissance," an unpublished manuscript prepared for John M. Reilly and Robert B. Stepto, eds., Afro-American Literature: Reconstruction of a Literary History (New York: Modern Language Association).

${ }^{7}$ Robert E. Park, "Racial Assimilation in Secondary Groups"(1913), rpt. in Race and Culture: Essays in the Sociology of Contemporary Man (New York: Free Press, 1964), p. 219.

${ }^{8}$ In an article originally published in 1923, Park outlines this "natural history" in three stages: "(1) the struggles of the rural populations to get to the city and appropriate the cultures of the cities for their own uses; (2) ... the struggles of the disinherited, neglected, if not oppressed, peoples to emancipate themselves culturally and economically; (3) . . . [the resultant] general expansion of the people, geographical as well as cultural, accompanied by a marked elevation and intensification of the lives of the individuals and of the peoples as a whole" ("Negro Race Consciousness," rpt. in Race and Culture, pp. 298-99).

"Human Migration and the Marginal Man" (1928), rpt. in Race and Culture, p. 350 .

${ }^{10} \mathrm{Rpt}$. in Voices from the Harlem Renaissance, ed. Nathan Irvin Huggins (New York: Oxford Univ. Press, 1976), p. 397. Future references to the essay will be noted in the text.

11 The Unfinished Quest of Richard Wright (New York: Morrow, 1973), pp. 143-44.

12Richard Wright, 12 Million Black Voices: A Folk History of the Negro in the United States (New York: Viking Press, 1941). Page references are noted in the text.

13This discussion is influenced by Albert $J$. Raboteau's " A Fire in the Bones': The Afro-American Chanted Sermon,"an unpublished manuscript prepared for Afro-American Literature: Reconstruction of a Literary History.

${ }^{14}$ See American Hunger, p. 77.

\title{
THE SEXUALIZATION OF RACISM IN RICHARD WRIGHT'S "THE MAN WHO KILLED A SHADOW"
}

\author{
EARLE V. BRYANT*
}

When Michel Fabre speaks of Richard Wright's "linking of racism and sexuality" in "The Man Who Killed a Shadow," he is pinpointing Wright's central concern in the story"; for in "The Man Who Killed a Shadow" Wright focuses on the race-sex nexus that white America has effected and incorporated into its cultural and social fabric. For the most part, this race-sex nexus springs from white America's traditionally stereotypical conception of black male sexuality and, what is intrinsically related to this, the white female's reputed conditioned response to the black male as a sexual being. ${ }^{2}$ Calvin C. Hernton has termed this particular phenomenon "the sexualization of racism," 3 and in "The Man Who Killed a Shadow" it is on precisely this phenomenon that Wright is focusing attention. On one level of the story, he is dramatizing the tragic effects that racism's sexualization has on the lives of two people, a black male and a white female. On another, wider level, he is intimating that white America has transmuted the black male-white female relationship into a terror-filled and murderous experience.

In dealing with the subject of racism's sexualization in "The Man Who Killed a Shadow," Wright is treading on ground that has been well-tilled. To be sure, the stereotypical conception of black male sexuality is one of the most prevalent stereotypes in white America's racial mythology.

*Earle Bryant teaches English at the University of New Orleans and has, for the 1982-83 academic year, been awarded a fellowship from the Southern Fellowships Fund to work on a remedial text.
Addressing the issue of race and sex in America, Calvin C. Hernton has maintained that "the American brand of sex and racism [has] distorted and vulgarized the perception of black men as sexual beings .... The most blatant of the cultural stereotypes about the [black male] is the myth of [his] sexual virility. . . . whites conceive of the [black] male predominantly in genital terms - that is, as a 'bull' or as some kind of 'walking phallus.' "4

John Dollard, in his classic study of race relations, has voiced similar sentiments. Writing in reference to "the potency attributed to the Negro male," Dollard states: "In the folk imagination of the whites, Negro men are viewed as especially virile and capable in the sphere [of sex]."s Proceeding along these same lines, psychiatrists William $\mathbf{H}$. Cobbs and Price M. Grier have stated that "the black man occupies a very special sexual role in American society. He is seen as the ultimate in virility and masculine vigor."6 Similarly, psychiatrist Alvin F. Poussaint writes that, "historically, black males have been portrayed as dark merchants of uncontrolled animal sexuality. . . . From North to South it is popularly believed that black men are tireless studs." 7 This notion has recently been reiterated by Michele Wallace: "For hundreds of years, white men [have] written and spoken about how the black man [is] 'hung like an ape,' about how he fuck[s] like an animal. The big black prick pervade[s] the white man's nightmare."8 In fine, the image of the black male as a sexual dynamo is deeply ingrained in (to borrow Poussaint's phrase) the "sexual folklore" of white America.9 
Intrinsically related to the stereotypical conception of the black male as a sexual athlete is the sexual attraction which the white female allegedly feels for the black male. As Hernton states: "Against the backdrop of taboo, of lies and stereotypes about the sexuality of Negroes, theoretically the black man becomes the most powerful sex attraction in the life of the white woman. . . . In [her] mind, the Negro is a superior sexual animal. It matters little whether he actually is or not; she believes it because her culture has taught her to believe it."10 Writing in a similar vein, Amiri Baraka has declared that "the white woman [is] supposed to be intrigued by the black man . . . because he [is] basic and elemental emotionally . . . , therefore 'wilder,' harder, and almost insatiable in his lovemaking." 11 As both Hernton and Baraka point out, the sexual attraction that the white female reputedly feels for the black male is essentially a corollary of the projected sexual image of the black male-is, in effect, one of the by-products of sexualized racism.

It is against precisely such a backdrop that "The Man Who Killed a Shadow" can best be understood. The story itself centers around Saul Saunders, a black janitor, and Maybelle Houseman, the white "shadow-woman"12 in charge of the small library that Saul cleans every day. Although the shadow-woman never speaks to Saul except to toss him an occasional, curt "good morning," Saul frequently notices that, when the shadow-woman thinks he is not looking, she stares at him "in a most peculiar way." 13 However, whenever Saul catches her doing this and returns her stare, she "look[s] away quickly, as though ashamed" (p. 161). The shadow-woman's behavior troubles Saul, who wants only to be left in peace. " What in hell does she want from me?" " (p. 161) is the question that nags him. The answer, which he learns in the story's pivotal scene, brings the world crashing down around his ears.

The story's pivotal scene is the shadow-woman's attempt to seduce Saul, an attempt which subsequently leads to her death at Saul's hands. One of Wright's most gripping treatments of the encounter between the black male and the white female, the scene embodies the essence of what Wright is intent on conveying in "The Man Who Killed a Shadow." In the scene, Saul and the shadow-woman are alone in the library. As he is dusting, he notices once again that she is staring at him. Only this time she speaks:

\footnotetext{
"Why don't you clean under my desk?" she asked him in a tense but controlled voice.

"Why, ma'am," he said slowly, "I just did."

"Come here and look," she said, pointing downward.

He replaced the book on the shelf. She had never spoken so many words to him before. He went and stood before her and his mind protested against what his eyes saw, and then his senses leaped in wonder. She was sitting with her knees sprawled apart and her dress was drawn halfway up her legs. He looked from her round blue eyes to her white legs whose thighs thickened as they went to a $\mathrm{V}$ clothed in tight, sheer, pink panties; then he looked quickly again into her eyes.... Saul was so startled that he could not move.

(pp. 162-63)
}

As Wright depicts it, the scene is a graphic illustration of the operation of sexualized racism. For in the eyes of the shadow-woman, Saul is a sex object-not because he is a man, but because he is a black man. Viewed in this light, the shadow-woman can be said to have labeled or typed Saul, to have assigned him a role in keeping (so she believes) with "his kind." At base, the shadow-woman's conception of Saul is founded upon a kind of syllogistic reasoning that is at once faulty and decidedly racist. Sketched in syllogistic form, the woman's reasoning is something on the order of this: All black males are sexual athletes; Saul is a black male; ergo, Saul is necessarily a stud. As the shadow-woman discovers to her detriment, her conclusion is invalid because her major premise is a sweeping generalization-a logical fallacy springing from sexualized racism.

With respect to Wright's portrayal of the shadowwoman's overall behavior during her attempted seduction of Saul, it is enlightening to recall one of Hernton's statements regarding the white female's reputed ambivalence toward the black male. The black male, Hernton writes, owing to white America's projection of him as a satyr, "becomes the center of the white woman's sexual life-she elevates him to the status of a god-phallus; she worships, fears, desires, and hates him." 14 The intertwined desire-hatred of which Hernton speaks is amply illustrated in the shadow-woman's overall behavior in the scene under discussion-behavior which, upon closer inspection, reveals her ambivalence to Saul.

On the one hand, as her exhibitionist posture indicates, she is patently attracted to him sexually and in fact wants him to take her up on her "invitation": Her legs are spread "so wide apart that he felt that she was naked.... and she was sitting as though about to spring upon him and throw her naked thighs about his body" (p. 163). Indeed, the shadow-woman's exhibitionism is nothing else if not an attempt to seduce Saul. In addition, one should not overlook the obvious double entendre present in the woman's heated reply to Saul when he implores her to stop " 'making trouble' ": “ 'Why don't you do your work?' She blazed at him" (p. 163; emphasis added). Immediately after she barks this "command," Wright, as if to point up the sexual thrust of the woman's words, hurriedly draws the reader's attention to "her gaping thighs," to her "legs . . . spread wide apart" (p. 163). Needless to say, the kind of "work" to which the shadow-woman is alluding is not janitorial labor.

On the other hand, the shadow-woman's feeling for Saul is by no means one of unqualified sexual attraction. As Wright is careful to point out, her exhibitionistic behavior is set against, and qualified to an extent by, her discernible disinclination to behave in such a manner. Wright's description of the shadow-woman's face and (once again) posture clearly indicates her reluctance to participate in the attempted seduction: "Her face was a beet red, but she sat very still, rigid, as though she was being impelled into an act which she did not want to perform but was being driven to perform" (p. 163; emphasis added). Aside from Wright's rather explicit mention of the role that psychological coersion plays in the woman's conduct, one should note that Wright describes the woman's face as "beet red." Now admittedly, one would be hard put to say whether the woman's flushed visage is caused by embarrassment or sexual arousal. The probability, however, is that her "beet red" face is as much a result of embarrassment, or shame, as it is of sexual excitement. What's more, the shad ow-woman's reference to Saul as " 'you black nigger!' " (p. 163) should not go unnoticed. Her use of this epithet forcefully reveals the underlying contempt which she feels for him. ${ }^{15}$ The elements of compulsion and aversion, then, are unmistakably part of the shadow-woman's overall feeling for Saul. 
If the shadow-woman's response to Saul is an amalgam of attraction and aversion, Saul's reaction to her and to her attempt to seduce him is not at all ambivalent: What he feels are anger and fear unalloyed with sexual arousal. ${ }^{16} \mathrm{He}$ makes no move, as the shadow-woman had undoubtedly hoped (and feared) he should, to take her up on her "invitation." Instead, angered by the insult she has hurled at him and by the dangerous situation she is placing him in, he slaps her across the face. Saul's anger, however, is only momentary; it soon gives way to another, dominant emotionfear. For after Saul slaps her, the shadow-woman begins to scream hysterically, and Saul becomes terrified. It is at this point, in what is one of the most prolonged and gruesome murder scenes Wright ever wrote, that Saul assails and kills the shadow-woman.

As Wright makes clear in the story, when Saul brutally assaults the shadow-woman, his intent is not to kill her, but rather to silence her, to stop her from "screaming a scream that meant death" (pp. 164-65). In fact, after he finally succeeds in silencing her, Saul gives absolutely no thought to the extent of the shadow-woman's injuries, much less to the possibility that she might be dead. All that matters to him is that the woman has finally stopped screaming and that he is safe.

In essence, Saul inadvertently kills the shadow-woman for the same reason that Bigger Thomas in Native Son inadvertently kills Mary Dalton - fear of being caught in an ostensibly compromising situation with a white woman:

\begin{abstract}
The woman was screaming continuously .... In her scream he heard the sirens of the police cars that hunted down black men in the Black Belts and he heard the shrill whistles of white cops running after black men and he felt again in one rush of emotion all the wild and bitter tales he had heard of how whites always got the black who did a crime and this woman was screaming as though he had raped her. (p. 164; emphasis added)
\end{abstract}

In attempting to silence the shadow-woman, then, Saul is impelled by a keen awareness of the taboo white society has placed on black male-white female encounters that have even a hint of the sexual about them, and by an equally keen awareness of the consequences that await any black male brash enough to "step out of line" with a white woman.

Tyree Tucker, a major black character in Wright's novel The Long Dream, voices Saul's awareness of this taboo and of what happens to black men who disregard it. At one point in the novel, a young black man is accused of sexual misconduct with a white woman, and an enraged white mob lynches him after torturing him long and unmercifully. Tyree makes use of this tragic incident to educate his young son Fish in the ways of the white world. In an impassioned speech, Tyree tells his son: "Lissen, Fish: NEVER LOOK AT A WHITE WOMAN! YOU HEAR? . . Keep away from 'em, son. When you in the presence of a white woman, remember she means death!' "17 It is precisely Saul's knowledge that the white woman "means death" for the black man that prompts him to act when the shadowwoman screams.

As the story evinces, both Saul and the shadow-woman are victims of racism's sexualization. In essence, both have been victimized through conditioning. As the shadowwoman sees him, Saul is a typical "nigger buck," hot to trot, and accordingly she feels herself gravitating toward this supposed sexual dynamo. This is how she has been condi- tioned to view, and to respond to, "his kind." For his part, Saul has been conditioned to "stay in his place" vis à vis the white female. He is ever mindful of the Great Taboo, of white America's warning to black males: "If you touch a white woman, you'll be killed!" 18 Given the forma mentis of each character, their encounter could not have ended any other way than it does.

"The Man Who Killed a Shadow" is by no means Wright's only treatment of the subject of racism's sexualization. For example, in "Big Boy Leaves Home," one of Wright's earliest short stories, racism's sexualization is a major concern. ${ }^{19}$ Too, in The Long Dream, the last novel Wright published before his death, the subject occupies a central position. And there is, of course, Wright's magnum opus, Native Son, in which this issue receives far from scant attention. ${ }^{20}$ But it is in "The Man Who Killed a Shadow" that Wright gives the subject of racism's sexualization its most concentrated and forceful treatment.

\section{NOTES}

${ }^{1}$ The Unfinished Quest of Richard Wright (New York: Morrow, 1973), p. 305.

${ }^{2}$ For an in-depth treatment of this matter, see Calvin C. Hernton, Sex and Racism in America (New York: Grove, 1966).

${ }^{3}$ See Sex and Racism in America, pp. 3-8.

${ }^{4}$ Sex and Racism in America, pp. 26, 116, 39.

${ }^{5}$ Caste and Class in a Southern Town, 3rd ed. (1949; rpt. Garden City, NY: Doubleday, 1957), pp. 161, 160.

${ }^{6}$ Black Rage (New York: Basic Books, 1968), p. 87

${ }^{7}$ Why Blacks Kill Blacks (New York: Emerson Hall, 1972), pp. 91, 92.

${ }^{8}$ Black Macho and the Myth of the Superwoman (New York: Dial, 1979), p. 71 .

${ }^{9}$ Why Blacks Kill Blacks, p. 96.

${ }^{10}$ Sex and Racism in America, p. 26.

${ }^{11}$ Home: Social Essays (New York: Morrow, 1966), pp. 221-22.

12Throughout the story Wright consistently refers to Maybelle Houseman as "the woman" or "the white-shadow woman." It is not until Saul's court room appearance at the end of the story that the reader, along with Saul himself, learns her name. Wright's purpose in withholding the shadowwoman's name is to invest her with a kind of anonymity, thereby underscoring Saul's perception of her as a "shadow."

${ }^{13}$ Richard Wright, "The Man Who Killed a Shadow," in Eight Men (1961; rpt. New York: Pyramid, 1969), p. 161. All references to "The Man Who Killed a Shadow" are to the Pyramid edition and are, hereafter, cited parenthetically in the text.

${ }^{14}$ Sex and Racism in America, p. 26; emphasis added.

${ }^{15}$ In connection with the shadow-woman's reference to Saul as " 'you black nigger," "it is enlightening to note Hernton's observation that "during the act of intercourse [black males'] white mates frequently utter the most racially vulgar and offensive epithets conceivable, such as, 'Rape me, nigger, rape me!' " (Sex and Racism in America, p. 50). Hernton's point is that racial name-calling by the sexually aroused white female often enhances her sexual excitement. Viewed in this light, the shadow-woman's racist utterance can be seen not only as an indication of her contempt for Saul but also as a possible "self-turn-on."

${ }^{16}$ Wright is explicit about Saul's lack of sexual interest in the shadowwoman. For example, after Saul has killed her, he takes off her panties and uses them to wipe away the blood on the floor: "... . he sat her against the wall, stripped her of her pink panties-and not once did he so much as glance at her groin-wetted them and swabbed up the spots..." (p. 166; emphasis added).

${ }^{17}$ The Long Dream (1958; rpt. Chatham, NJ: Chatham Bookseller, 1969), p. 64 .

${ }^{18}$ The Long Dream, p. 149.

${ }^{19}$ For an acute analysis of Wright's treatment of black male sexuality as an aphrodisiac of sorts in "Big Boy Leaves Home," see Dan McCall, The Example of Richard Wright (New York: Harcourt, 1969), pp. 40-42.

${ }^{20} \mathrm{McCa}$ Cand Keneth Kinnamon, among others, have drawn attention to this point. See McCall, p. 73, and Keneth Kinnamon, The Emergence of Richard Wright (Urbana: Univ. of Illinois Press, 1973), pp. 139-40. 